\title{
ВІДХОДИ ВИРОЩУВАННЯ ПРЕДСТАВНИКІВ РОДУ ЕХІНАЦЕЯ (ECHINACEA MOENCH) ЯК ПЕРСПЕКТИВНЕ ДЖЕРЕЛО БІОЛОГІЧНО АКТИВНИХ РЕЧОВИН
}

\section{Рецензент - доктор сільськогосподарських наук, професор М. Я. Шевніков}

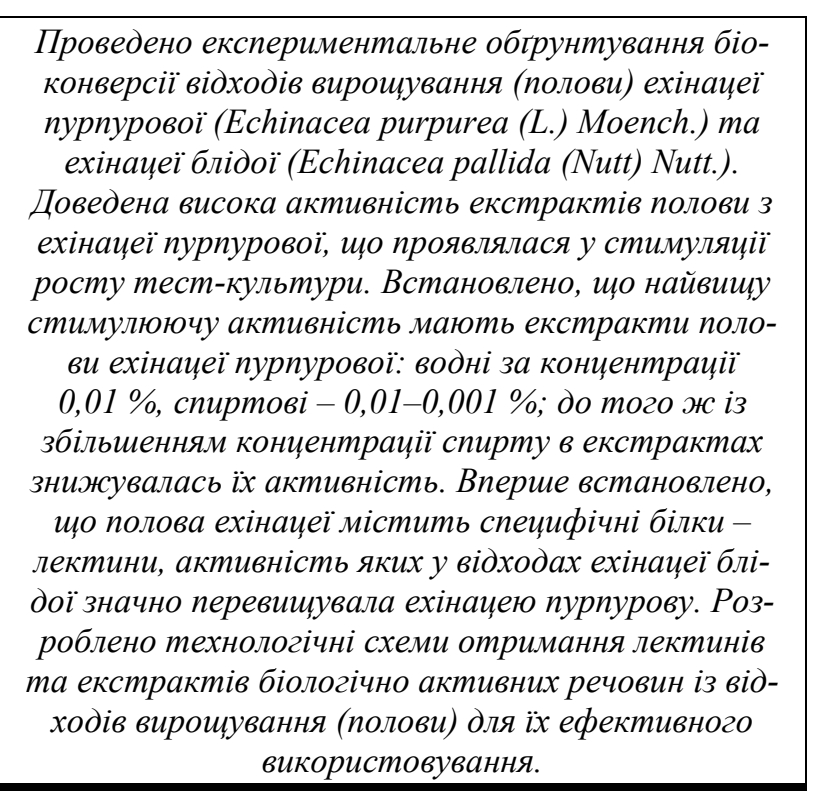

Ключові слова: відходи вирощування, полова, біоконверсія, лектини, біологічно активні речовини, Echinacea purpurea (L.) Moench, Echinacea pallida (Nutt.) Nutt.

Постановка проблеми. Представники роду ехінацея (Echinacea Moench) - відомі лікарські, кормові, декоративні та медодайні рослини, що містять у сировині унікальне поєднання біологічно активних речовин. Завдяки цьому 3 надземної маси і кореневищ із коренями ехінацеї виготовляють медичні препарати імуностимулюючої дії, що знаходять використання в медицині, ветеринарії; екстракти додають також у харчові продукти, напої тощо [9].

У процесі вирощування ехінацеї в кінці вегетаційного періоду після збирання насіння залишається полова, що містить рештки стебел та кошиків ехінацеї.

Представляє сенс біоконверсія цих відходів: у них може залишатися певна кількість активних речовин, що можуть знайти застосування у медицині, сільському господарстві.
Аналіз основних досліджень і публікацій, у яких започатковано розв'язання проблеми. Нині досить актуальною є проблема утилізації відходів фармацевтичного виробництва [10]. Наявність у відходах переробки лікарських рослин біологічно активних речовин широкого спектру дії вказує на доцільність використання їх у медицині, біотехнології, біохімії, харчових технологіях, косметології, парфумерній промисловості, сільському господарстві тощо. Відомо, що відходи лікарської сировини містять у собі значну кількість біологічно активних сполук, які можна ефективно виділити та очистити [11]. Так, шрот обліпихи багатий на кумарини, поліфенольний комплекс, урсолову кислоту, ліпіди $[1,5]$. У відходах, що утворилися після виробництва препарату із звіробою, знайдені гіперицин, кверцетин, оксикоричні кислоти [3]. Як свідчать дослідження, препарат із шроту листя алое має рістрегулюючу активність у ході передпосівної обробки зернових культур [1].

Враховуючи те, що сировина ехінацеї пурпурової та ехінацеї блідої містить широкий спектр біологічно активних компонентів [7,8], можна припустити: відходи вирощування також містять речовини, що володіють біологічною активністю.

Відомо, що у період дозрівання насіння кошики і стебла втрачають воду й змінюють свій хімічний склад, у тому числі й співвідношення біологічно активних речовин [6]. Тому можна прогнозувати, що біологічна активність екстрактів полови і трави буде різною.

Мета досліджень. Метою дослідження було вивчення біологічної активності екстрактів відходів вирощування (полови) ехінацеї пурпурової (Echinacea purpurea (L.) Moench.) та ехінацеї блідої (Echinacea pallida (Nutt.) Nutt.) і з'ясування можливості використання їх як джерела біологічно активних речовин.

* Науковий керівник-кандидат сільськогосподарських наук С. В. Поспєлов 


\section{СТОРІНКА МОЛОДОГО ВЧЕНОГО}

Методика проведення досліджень. Дослідження проводили методом біологічних тестів на паростках ячменю посівного (Hordeum sativum Lessen.) сорту Персей протягом 20062009 років. Для цього відсортоване насіння ячменю на 24 години замочували у воді, після чого розкладали проросле насіння по 20-25 штук у чашки Петрі з екстрактами (4-5 мл розчину певної концентрації у кожну чашку) в трьохразовій повторності за температури $20-25{ }^{0} \mathrm{C}$. Контрольні заміри довжини коренів та колеоптилів проводили через 24, 48, 72 та 96 годин [2]. Статистична обробка отриманих даних здійснювалася за допомогою комп'ютерної програми Excel.

Для оцінки біологічної активності екстрактів полови ми використали два методи екстрагування: водне та спиртове (з доведенням вмісту етилу до $20 \%$ та $40 \%$ ). Водні екстракти виготовляли шляхом настоювання полови у дистильованій воді протягом двох годин за кімнатної температури. Використовували водні розчини таких концентрацій: $0,1 \%, 0,01 \%, 0,001 \%$. Спиртові екстракти виготовлялися методом екстрагування. У дослідженні використані $20 \%$ та 40 \% спиртові розчини; в контрольних варіантах - дистильована вода [2].

Виділення лектинів із відходів вирощування ехінацеї проводилося за методикою низькотемпературного етанольного фракціонування [4]. Визначення активності лектинів в екстрактах полови ехінацеї проводили за гемаглютинуючою активністю еритроцитів крові людини в системі $\mathrm{ABO}$ за загальноприйнятими методиками [4].
Результати досліджень. Результати вивчення впливу водних екстрактів із полови ехінацеї пурпурової на корені та колеоптилі у зернівок ячменю, що проростали, наведені в таблиці 1.

Аналіз отриманих даних показав, що витяжки полови ехінацеї пурпурової в усіх досліджених концентраціях проявили помітну стимулюючу активність на ріст коренів: за вимірювання довжини коренів через 24 години дослідні варіанти достовірно переважали контрольні на 7,4-9,3\%. За наступних вимірювань (на 48-у і 72-у години) довжина коренів у дослідних варіантах перевищувала контроль на 7,56-10,8\% відповідно. Лише за концентрації $0,01 \%$ через 48 годин довжина коренів була дещо нижчою за контроль (на 4,08\%).

Водні екстракти полови ехінацеї пурпурової також стимулювали ріст колеоптилів ячменю в дослідах: упродовж усього терміну досліду показники середньої довжини колеоптилів у більшості варіантів були вищими за контроль. За вимірювання через 24 години в дослідних варіантах довжина достовірно перевищувала контроль на $1-43,7 \%$. Найвища стимулююча активність була притаманна екстракту в концентрації $0,1 \%$. Під час наступних вимірювань у більшості варіантів на 48-у та 72-у години довжина пагонів у концентраціях $0,1 \%$ та $0,01 \%$ перевищувала контрольні показники на $14,8-17,7 \%$ та 8,7-16,0\% відповідно. Найбільша активність виявлена в концентрації 0,01 \% (досліджувані варіанти через 48 годин на 17,7 \% були більшими за контроль).

\section{1. Вилив водних екстрактів полови ехінацеї пурпурової на довжину коренів та колеоптилів ячменю, мм/士 \% до контролю}

\begin{tabular}{|c|c|c|c|c|c|c|c|c|c|}
\hline \multirow{3}{*}{\multicolumn{2}{|c|}{ Експозиція }} & \multirow{2}{*}{\multicolumn{2}{|c|}{ Контроль }} & \multicolumn{6}{|c|}{ Концентрація } \\
\hline & & & & \multicolumn{2}{|r|}{$0,1 \%$} & \multicolumn{2}{|c|}{$0,01 \%$} & \multicolumn{2}{|c|}{$0,001 \%$} \\
\hline & & корені & колеоптилі & корені & колеоптилі & корені & колеоптилі & корені & колеоптилі \\
\hline \multirow{2}{*}{ 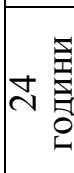 } & $\begin{array}{c}\text { значення, } \\
\text { мм }\end{array}$ & $\begin{array}{c}27,0 \\
\pm 0,59\end{array}$ & $\begin{array}{c}5,65 \\
\pm 0,75\end{array}$ & $\begin{array}{l}29,52 \\
\pm 0,63\end{array}$ & $\begin{array}{c}8,13 \\
\pm 0,88\end{array}$ & $\begin{array}{l}29,43 \\
\pm 0,74\end{array}$ & $\begin{array}{c}5,7 \\
\pm 0,71\end{array}$ & $\begin{array}{l}29,21 \\
\pm 0,62\end{array}$ & $\begin{array}{c}5,9 \\
\pm 0,71\end{array}$ \\
\hline & $\begin{array}{c} \pm \text { до кон- } \\
\text { тролю }\end{array}$ & $100 \%$ & $100 \%$ & $+9,3 \%$ & $+43,7 \%$ & $+9,0 \%$ & $+1,0 \%$ & $+7,4 \%$ & $+4,42 \%$ \\
\hline \multirow{2}{*}{ 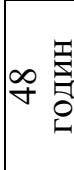 } & $\begin{array}{c}\text { значення, } \\
\text { мм }\end{array}$ & $\begin{array}{l}60,42 \\
\pm 0,83\end{array}$ & $\begin{array}{l}30,05 \\
\pm 1,28\end{array}$ & $\begin{array}{l}64,99 \\
\pm 0,86\end{array}$ & $\begin{array}{l}34,51 \\
\pm 1,36\end{array}$ & $\begin{array}{l}65,43 \\
\pm 0,88\end{array}$ & $\begin{array}{l}35,38 \\
\pm 1,57\end{array}$ & $\begin{array}{l}57,95 \\
\pm 0,84\end{array}$ & $\begin{array}{l}29,13 \\
\pm 1,26\end{array}$ \\
\hline & $\begin{array}{c} \pm \text { до кон- } \\
\text { тролю }\end{array}$ & $100 \%$ & $100 \%$ & $\begin{array}{c}+7,56 \\
\%\end{array}$ & $+14,8 \%$ & $+10,8 \%$ & $+17,7 \%$ & $-4,08 \%$ & $-4,49 \%$ \\
\hline \multirow{2}{*}{$\therefore$} & $\begin{array}{c}\text { 3начення, } \\
\text { мм }\end{array}$ & $\begin{array}{l}87,45 \\
\pm 0,99\end{array}$ & $\begin{array}{c}52,51 \\
\pm 1,7 \\
\end{array}$ & $\begin{array}{l}97,80 \\
\pm 1,07\end{array}$ & $\begin{array}{c}56,72 \\
\pm 1,8 \\
\end{array}$ & $\begin{array}{c}89,15 \\
\pm 1\end{array}$ & $\begin{array}{l}60,93 \\
\pm 1,81 \\
\end{array}$ & $\begin{array}{l}91,59 \\
\pm 1,02\end{array}$ & $\begin{array}{l}54,69 \\
\pm 1,75 \\
\end{array}$ \\
\hline & $\begin{array}{c} \pm \text { до кон- } \\
\text { тролю }\end{array}$ & $100 \%$ & $100 \%$ & $\begin{array}{c}+11,8 \\
\%\end{array}$ & $+8,7 \%$ & $+1,9 \%$ & $+16,0 \%$ & $+4,73 \%$ & $+4,15 \%$ \\
\hline \multirow{2}{*}{ 잉 } & $\begin{array}{c}\text { 3начення, } \\
\text { мм }\end{array}$ & - & $\begin{array}{l}67,67 \\
\pm 1,95 \\
\end{array}$ & - & $\begin{array}{l}67,21 \\
\pm 1,91 \\
\end{array}$ & - & $\begin{array}{c}77,5 \\
\pm 2,03 \\
\end{array}$ & - & $\begin{array}{l}64,70 \\
\pm 1,87 \\
\end{array}$ \\
\hline & $\begin{array}{c} \pm \text { до кон- } \\
\text { тролю }\end{array}$ & - & $100 \%$ & - & $-0,6 \%$ & - & $+14,5 \%$ & - & $-4,3 \%$ \\
\hline
\end{tabular}




\section{СТОРІНКА МОЛОДОГО ВЧЕНОГО}

Активнішою за інші концентрації вона була i за наступного заміру (через 96 годин). Довжина колеоптилів у цих варіантах перевищувала контрольні на $14,5 \%$, тоді як за концентрацій $0,1 \%$ та $0,001 \%$ довжина колеоптилів була на $0,6 \%$ та $4,3 \%$ нижчою за контроль.

Завданням наших досліджень було й вивчення біологічної активності $20 \%$ і $40 \%$ спиртових екстрактів ехінацеї. Результати дослідження впливу $20 \%$ спиртових екстрактів полови ехінацеї пурпурової на проростки ячменю наведені у таблиці 2. Встановлено, що він проявляв рістстимулюючу активність на корені ячменю за концентрацій $0,01 \%$ та $0,001 \%$. Так, довжина коренів за першої експозиції на 8,10 \% і 10,18 \% перевищувала контроль. Водночас за концентрації розчину $0,1 \%$ екстракт пригнічував ріст коренів на 9,96 \%. У ході подальших вимірів спостерігалася подібна закономірність: на 48-му та 72-гу години концентрації $0,01 \%$ та 0,001 \% дещо стимулювали тест-систему (на $2,83 \%$ i $2,35 \%$ - через 48 годин, і 9,12 та $16,3 \%$ - 72 години). За концентрації $0,1 \%$ екстракт значно пригнічував ріст коренів на $16,09 \%$ через 48 годин та на 9,26\% - через 72 години.

Таким чином, найбільшу ріст-стимулюючу дію на корені досліджувані екстракти проявляли після 48 годин за концентрацій $0,01 \%$ та $0,001 \%$.

Аналіз результатів дослідження дії $20 \%$ спиртових екстрактів полови ехінацеї пурпурової на довжину колеоптилів показав, що вони більш активно впливали на ріст пагонів ячменю порівняно 3 довжиною коренів. Довжина колеоптилів через 48 годин у дослідних варіантах виявилася значно більшою за їх довжину у контролі, і лише за концентрації $0,1 \%$ вона була на $6,16 \%$ меншою. Наступні вимірювання свідчать про певну тенденцію до збільшення довжини колеоптилів у дослідних варіантах: екстракти всіх концентрацій були ефективніші за контроль на $6,94 \%, 14,48 \%$ та $22,2 \%$ через 72 години та на 8,07\%, 12,15\%, 11,67\%через 96 годин досліду. Таким чином, $20 \%$ спиртові витяжки полови ехінацеї пурпурової в усіх концентраціях впливали на ріст пагонів ячменю, що свідчить про наявність у сировині біологічно активних речовин.

Результати вивчення впливу $40 \%$ спиртових екстрактів полови ехінацеї пурпурової на довжину коренів ячменю наведені у таблиці 3. Їх аналіз показав: ці екстракти в цілому пригнічували ріст кореневої меристеми ячменю. Однак слід зазначити, що дана активність була виявлена не на всіх етапах вимірювання.

На 24-у годину досліду довжина коренів у варіантах, оброблених спиртовими екстрактами за концентрації $0,01 \%$ та $0,001 \%$, виявилася більшою за контроль на 7,74 \% та 7,52 \% відповідно. На варіанті з концентрацією розчину $0,1 \%$ спостерігалося суттєве пригнічення (на $32,10 \%$ ).

\section{2. Вилив 20 \% спиртових екстрактів полови ехінацеї пурпурової на довжину коренів та колеоптилів ячменю, мм/士 \% до контролю}

\begin{tabular}{|c|c|c|c|c|c|c|c|c|c|}
\hline \multirow{3}{*}{\multicolumn{2}{|c|}{ Експозиція }} & \multirow{2}{*}{\multicolumn{2}{|c|}{ Контроль }} & \multicolumn{6}{|c|}{ Концентрація } \\
\hline & & & & \multicolumn{2}{|c|}{$0,1 \%$} & \multicolumn{2}{|c|}{$0,01 \%$} & \multicolumn{2}{|c|}{$0,001 \%$} \\
\hline & & корені & $\begin{array}{c}\text { колеоп- } \\
\text { тилі }\end{array}$ & корені & $\begin{array}{c}\text { колеоп- } \\
\text { тилі }\end{array}$ & корені & $\begin{array}{c}\text { колеоп- } \\
\text { тилі }\end{array}$ & корені & $\begin{array}{c}\text { колеоп- } \\
\text { тилі }\end{array}$ \\
\hline \multirow{2}{*}{ 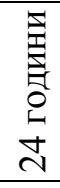 } & $\begin{array}{c}\text { значення, } \\
\text { мм }\end{array}$ & $\begin{array}{l}13,45 \\
\pm 0,36 \\
\end{array}$ & - & $\begin{array}{l}12,11 \\
\pm 0,35 \\
\end{array}$ & . & $\begin{array}{l}14,82 \\
\pm 0,35 \\
\end{array}$ & & $\begin{array}{r}14,54 \\
\pm 0,35 \\
\end{array}$ & - \\
\hline & $\begin{array}{c} \pm \text { до конт- } \\
\text { ролю }\end{array}$ & $100 \%$ & - & $-9,96 \%$ & - & $+10,1 \%$ & - & $+8,1 \%$ & - \\
\hline \multirow{2}{*}{ 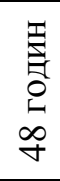 } & $\begin{array}{c}\text { значення, } \\
\text { мм }\end{array}$ & $\begin{array}{l}38,46 \\
\pm 0,87\end{array}$ & $\begin{array}{l}25,47 \\
\pm 0,66 \\
\end{array}$ & $\begin{array}{l}32,27 \\
\pm 0,84\end{array}$ & $\begin{array}{c}23,9 \\
\pm 0,84\end{array}$ & $\begin{array}{l}39,55 \\
\pm 0,80\end{array}$ & $\begin{array}{l}26,37 \\
\pm 0,59 \\
\end{array}$ & $\begin{array}{l}39,51 \\
\pm 0,89 \\
\end{array}$ & $\begin{array}{l}26,37 \\
\pm 0,65 \\
\end{array}$ \\
\hline & $\begin{array}{c} \pm \text { до конт- } \\
\text { ролю }\end{array}$ & $100 \%$ & $100 \%$ & $-16,09 \%$ & $-6,16 \%$ & $+2,83 \%$ & $+3,53 \%$ & $+2,35 \%$ & $+3,81 \%$ \\
\hline \multirow{2}{*}{ 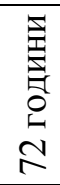 } & $\begin{array}{c}\text { значення, } \\
\text { мм }\end{array}$ & $\begin{array}{l}57,11 \\
\pm 1,27\end{array}$ & $\begin{array}{c}43,5 \\
\pm 1,84\end{array}$ & $\begin{array}{l}51,82 \\
\pm 1,11\end{array}$ & $\begin{array}{l}46,52 \\
\pm 1,65\end{array}$ & $\begin{array}{l}62,32 \\
\pm 1,22\end{array}$ & $\begin{array}{c}49,8 \\
\pm 1,47\end{array}$ & $\begin{array}{l}66,42 \\
\pm 1,20\end{array}$ & $\begin{array}{l}53,16 \\
\pm 1,58\end{array}$ \\
\hline & $\begin{array}{c} \pm \text { до конт- } \\
\text { ролю }\end{array}$ & $100 \%$ & $100 \%$ & $-9,26 \%$ & $+6,9 \%$ & $+9,12 \%$ & $+14,4 \%$ & $+16,3 \%$ & $+22,2 \%$ \\
\hline \multirow{2}{*}{ 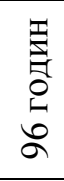 } & $\begin{array}{c}\text { значення, } \\
\text { мм }\end{array}$ & - & $\begin{array}{l}66,23 \\
\pm 3,37 \\
\end{array}$ & - & $\begin{array}{l}71,58 \\
\pm 3,04 \\
\end{array}$ & - & $\begin{array}{r}74,28 \\
\pm 2,57 \\
\end{array}$ & - & $\begin{array}{l}73,96 \\
\pm 3,02 \\
\end{array}$ \\
\hline & $\begin{array}{c} \pm \text { до конт- } \\
\text { ролю }\end{array}$ & - & $100 \%$ & - & $+8,0 \%$ & - & $+12,1 \%$ & - & $+11,6 \%$ \\
\hline
\end{tabular}




\section{СТОРІНКА МОЛОДОГО ВЧЕНОГО}

На 48-у годину довжина коренів у дослідних варіантах за концентрації 0,1\% була меншою за контроль на $37,61 \%$. За концентрацій $0,01 \%$ i $0,001 \%$ цей показник був меншим від контрольного на 10,06-3,36 \%. На кінець досліду (через 72 години) у цих варіантах довжина коренів хоча й була меншою за контроль, однак ця різниця виявилася не достовірною й склала лише 1,10 $2,29 \%$.

Що стосується довжини колеоптилів, то через 48 та 72 години експерименту в усіх досліджуваних варіантах довжина колеоптилів ячменю була меншою за контроль. За концентрації розчину $0,1 \%$ спостерігалося найбільше пригнічення росту, до того ж довжина колеоптилів виявилася меншою, ніж у контролі, на 20,16 \%. Через 72 години за всіх концентрацій екстракт пригнічував їх ріст. Лише на 96-ту годину експерименту відмічена несуттєва ріст-стимулююча активність екстрактів на колеоптилі (на 6,83-7,79 \%).

Таким чином, 40 \% спиртові витяжки 3 ехінацеї пурпурової в більшості проявили пригнічуючу дію як на ріст коренів, так і колеоптилів ячменю.

Ехінацея бліда досліджена не так досконало, як ехінацея пурпурова, але ії вивчення викликає значний науковий інтерес. Зважаючи на це, ми проводили дослідження наявності біологічно активних речовин у полові. Для цього вивчали дію екстрактів полови на ріст колеоптилів і ко- ренів ячменю (табл. 4).

Результати досліджень свідчать: екстракти полови ехінацеї блідої виявили незначну рістстимулюючу дію на довжину коренів ячменю. Так, через 24 години довжина коренів дослідних варіантів несуттєво перевищувала контрольні показники $(2-5 \%)$. За наступних вимірювань екстракти в основному пригнічували ріст коренів ячменю, - їх довжина через 72 години у переважаючої більшості дослідних варіантів була меншою за контрольні на 5-7 \%.

Аналогічні закономірності бачимо й у ході досліджень довжини колеоптилів. У перші 24 години за концентрацій $0,1 \%$ та $0,01 \%$ спостерігається незначне перевищення довжини колеоптилів у дослідних зразках порівняно 3 контролем. Ця різниця була достовірною і становила 4-7 \%.

Протягом наступної доби довжина колеоптилів у екстрактах в основному була меншою, ніж у контролі (в середньому на $4 \%$ ). Подібна закономірність спостерігалася і через 72 години довжина колеоптилів в екстрактах на 1-5 \% була нижчою за контроль.

Через 96 годин різниця довжини колеоптилів порівняно 3 контролем становила: у $0,1 \%$ екстрактах більшою на $1,2 \%$, у варіантах $0,001 \%-$ на $8,7 \%$ (різниця достовірна), а за концентрації $0,01 \%$ - меншою на $3 \%$. Таким чином, лише максимальне розведення проявило ріст-стимулюючу активність.

\section{3. Вилив 40 \% спиртових екстрактів полови ехінацеї пурпурової на довжину коренів}

та колеоптилів ячменю, мм/士 \% до контролю

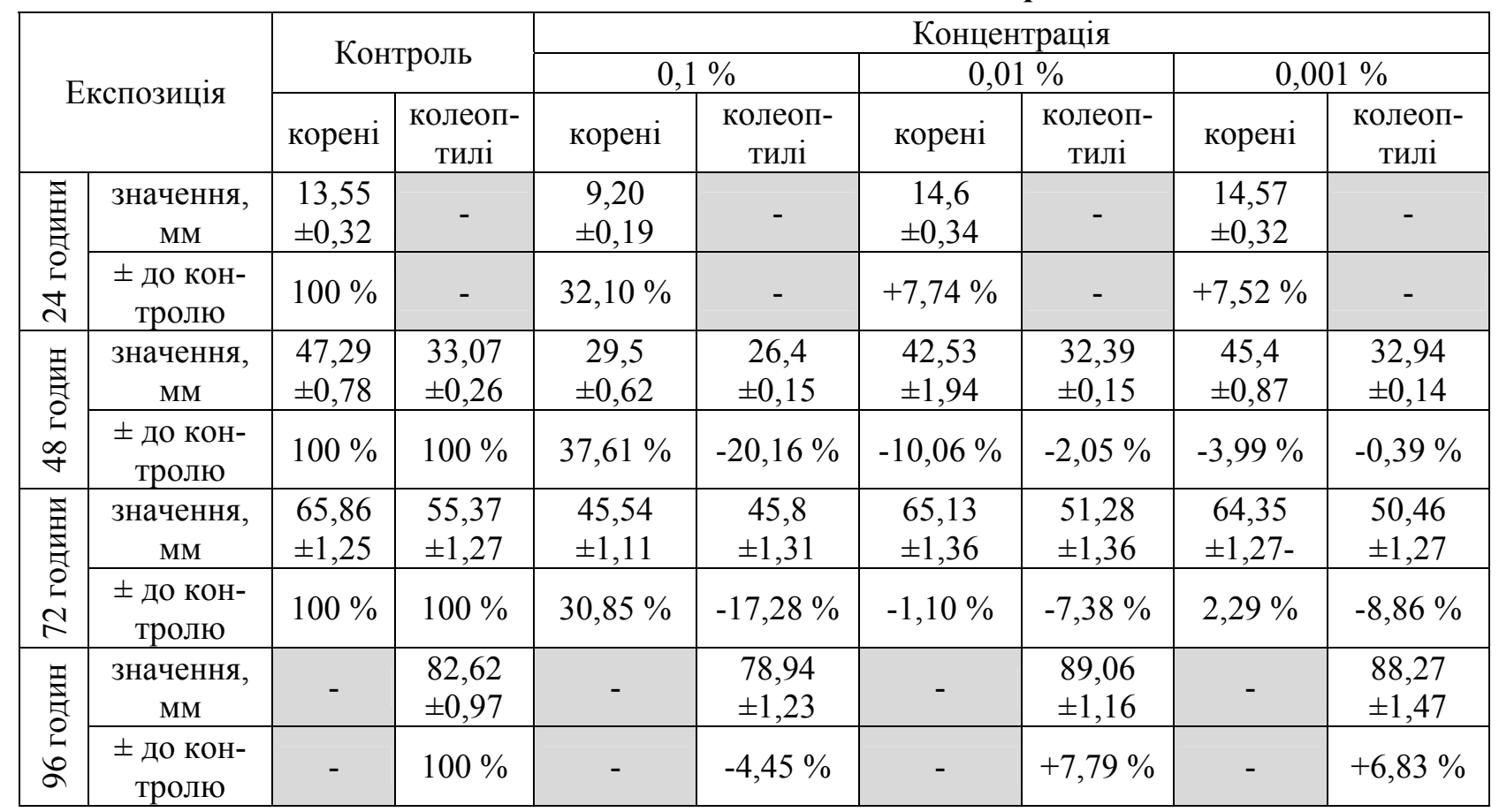


СТОРІНКА МОЛОДОГО ВЧЕНОГО

4. Вилив водних екстрактів полови ехінацеї блідої на довжину коренів і колеоптилів ячменю, мм/士 \% до контролю

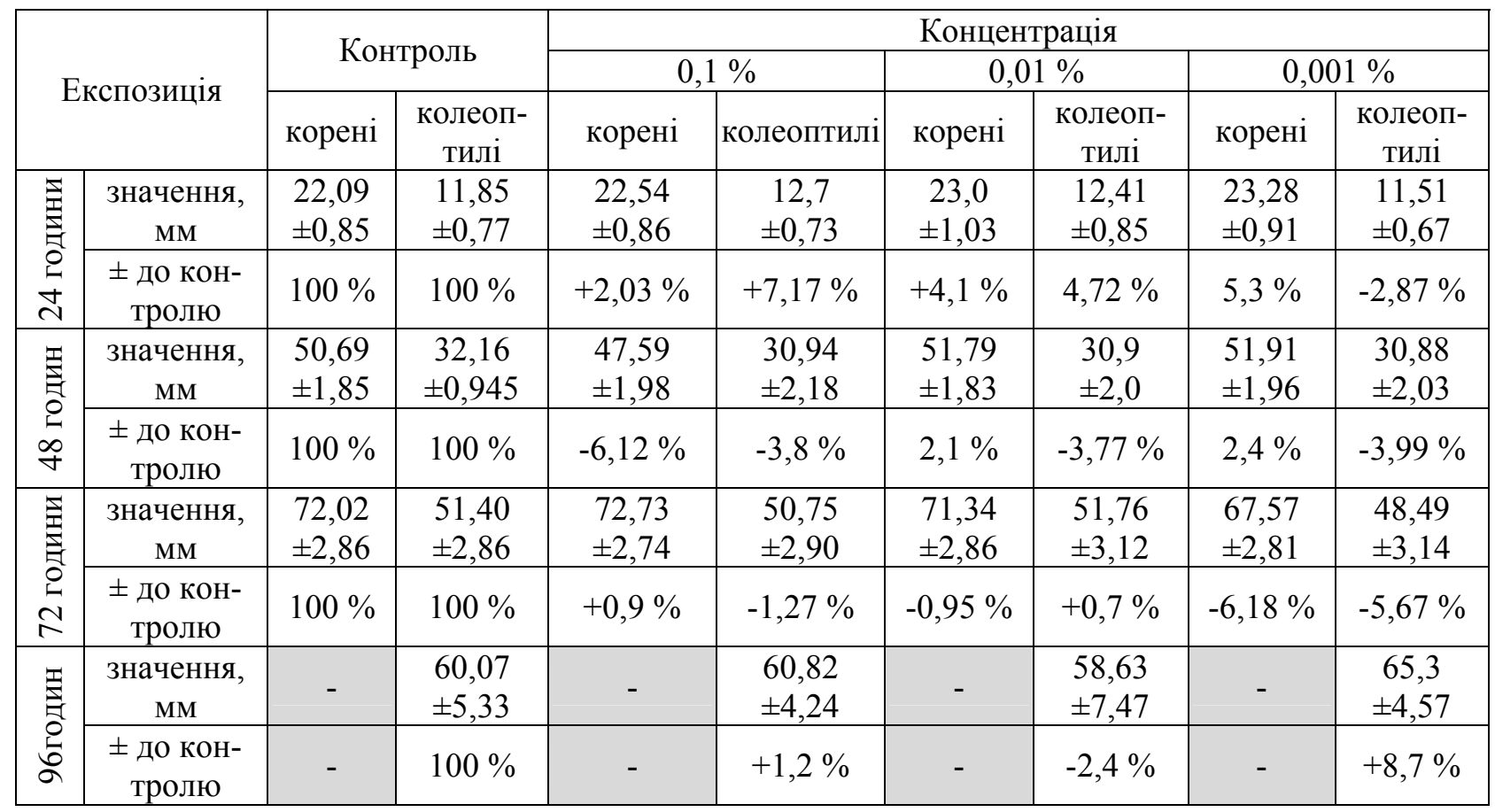

5. Активність лектинів у складових полови ехінацеї (одиниць)

\begin{tabular}{|c|c|c|}
\hline Об’єкт досліджень & Ехінацея пурпурова & Ехінацея бліда \\
\hline Стебла & $4,5-6,5$ & $16,0-20,0$ \\
\hline Квітколоже & 0,0 & $2,5-4,0$ \\
\hline Приквітки & 0,0 & $0,0-0,5$ \\
\hline
\end{tabular}

Екстракти полови ехінацеї блідої за концентрацій $0,1-0,001 \%$ слабо стимулювали ріст колеоптилів, але в кінцевому результаті лише концентрація $0,001 \%$ виявилася заслуговуючою на увагу. Очевидно, що для отримання ефекту стимуляції (а саме цей ефект є бажаним) потрібно діяти шляхом зменшення концентрацій діючих речовин.

Визначення активності лектинів в екстрактах складових полови ехінацеї, що проводили за гемаглютинуючою активністю еритроцитів крові людини, наведено у таблиці 5. Аналіз даних показав: найвища гемаглютинуюча активність притаманна екстрактам стебел ехінацеї блідої (16,0-20,0 од.), тоді як активність екстрактів квітколожа та приквітків становила $0,5-4,4$ од.

Що стосується активності лектинів у складових полови ехінацеї пурпурової, то вона була виявлена лише у екстрактах стебел (4,5-6,5 од.).

У лабораторних умовах нами було розроблено технологічні схеми отримання лектинів та екстрактів біологічно активних речовин із відходів вирощування (полови), що дає можливість ефективно їх використовувати (рис. 1-2).

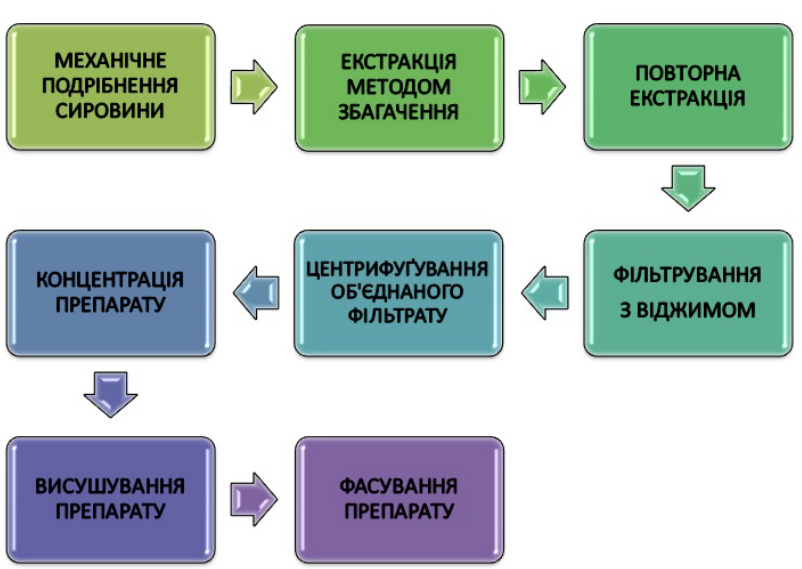

Рис. 1. Технологічна схема отримання екстракту біологічно активних речовин із відходів вирощування ехінацеї (полова)

Технологія отримання екстрактів біологічно активних речовин (рис. 1) заснована на властивостях окремих розчинників переводити їх $\mathrm{y}$ розчинні форми й виділяти їх із сировини. Для підвищення їх концентрації у фільтраті екстракція здійснюється методом збагачення, тобто, одним і тим же розчинником екстрагують три пар- 


\section{СТОРІНКА МОЛОДОГО ВЧЕНОГО}

тії сировини. Залишки корисних речовин із другої та третьої партій екстрагують незначною кількістю чистого розчинника 3 наступним віджимом та фільтруванням. Об'єднаний фільтрат центрифугують, концентрують шляхом вакуумного випарювання й висушують методом ліофілізації.

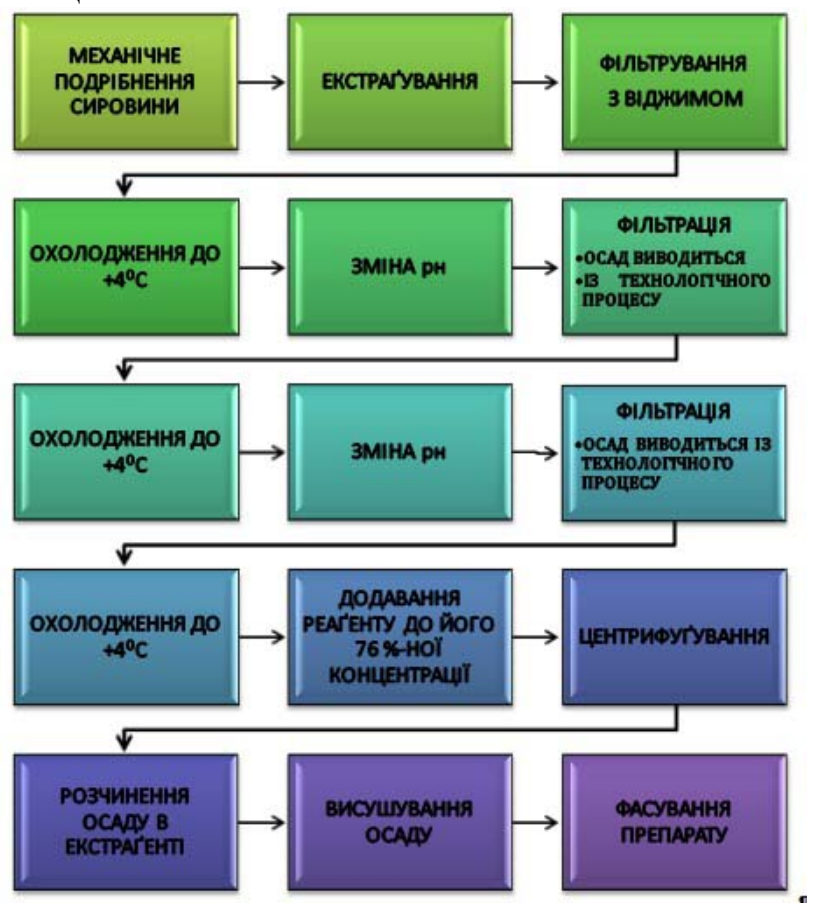

Рис. 2. Технологічна схема виділення лектинів із полови ехінацеї

\section{БІБЛІОГРАФІЯ}

1. Брыкалов А. В., Стерхова Д. В. Экологически безопасные препараты для сельского хозяйства // Биотех. В ФЦП «Интеграция»: заоч. науч.-практ. конф. - С.-Пб., окт., 1999; тез. докл. - С. 125-126.

2. Гродзинский A. М. Аллелопатия растений и почвоутомление. - К. : Наук. думка, 1991. - 431 с. 3. Левашева И. Г., Сокирко В. И., Жданов В. П.

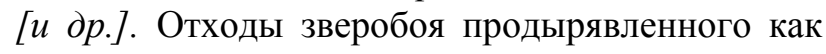
перспективный источник биологически активных соединений // 3-я Укр. конфер. по мед. ботан. - Тез. докл. - Ч. 1. - К., 1992. - С. 90.

4. Луциик М. Д., Панасюк Е. Н., Луиик А. Д. Лектины. - Львов : Вища школа, 1981. - 156 с.

5. Николаев С. М., Цыбиникова Д. Ц., Цырежапова О. Ц.

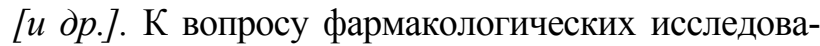
ний препаратов из отходов облепихи крушиновидной // Мат-лы 3-го Междунар. симпозиума по облепихе. - Барнаул, 1998. - С. 111-113.

6. Поспелов С. В., Кисличенко В. С., Самородов В. Н. $[u \quad \partial p$.$] . Биологически активные соединения пред-$ ставителей рода Echinacea Moench. Интродукция, сохранение и использование биологического раз-
Технологія отримання лектинів із відходів вирощування ехінацеї (рис. 2) заснована на властивостях деяких органічних розчинників переводити лектини із розчинного стану в нерозчинний.

\section{Висновки:}

1. Шляхом тестування на коренях і колеоптилях ячменю встановлено, що екстракти полови ехінацеї пурпурової та ехінацеї блідої містять біологічно активні речовини.

2. Водні екстракти полови ехінацеї пурпурової переважно стимулювали ріст коренів та пагонів ячменю. Найвища стимулююча активність була притаманна екстракту в концентрації $0,01 \%$.

3. $20 \%$ спиртові екстракти ехінацеї пурпурової проявляли ріст-стимулюючу активність на тест-систему за концентрацій 0,01-0,001 \% (від $+2,83 \%$ до $+16,3 \%)$ відносно контролю, в той час як $40 \%$ екстракти за цих концентрацій виявляли слабку стимулюючу активність лише на перших етапах дослідження.

4. Водні екстракти полови ехінацеї блідої через 24 години за всіх концентрацій слабо стимулювали ріст коренів ячменю, а за наступних вимірів спостерігалося пригнічення їх росту.

5. Встановлено, що виробничі відходи (полова) ехінацеї містить специфічні білки - лектини. В екстрактах ехінацеї блідої активність їх становила від 0,5 до 20,0 одиниць, а в ехінацеї пурпурової не перевищувала 6,5 одиниць.

нообразия мировой флоры. - Мат-лы Междунар. конф., посв. 80-летию Центр. бот. сада НАН Беларуси; в 2 ч. / Минск, 2012. - С. 157-161.

7. Поспєлов С. В., Шершова С. В. Дослідження біологічної активності лектинвмісних екстрактів ехінацеї пурпурової (Echinacea purpurea (1.) Moench.) // Вісник Полтавської державної аграрної академії. - 2012. - № 1. - С. 45-49.

8. Поспєлов С. В., Шериова С. В. Дослідження біологічної активності лектинвмісних екстрактів ехінацеї блідої (Echinacea pallida (Nutt.) Nutt.) // Вісник Полтавської державної аграрної академії. - 2012. - № 2. - C. 47-51.

9. Самородов В. Н., Поспелов С. В., Моисеева Г. Ф.

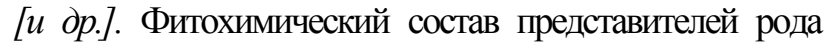
Эхинацея (Echinace Moench) и его фармакологические свойства // Хим.-фарм. журнал. - 1996. - № 4. - С. 32-37. 10. Сассон А. Биотехнология: свершения и надежды. - М. : Мир, 1987. - 411 с.

11. Селиванов А. С. Малоотходная технология биоконверсии растительного сырья : Автореф. дис. ... к.т.Н. - М., $1992 .-27$ c. 